\title{
Manure characteristics of small ruminants fed agroby- products in the guinea savannah agro-ecological zone of Ghana
}

\author{
K.O. ANSAH*, C. ANTWI, E.L.K. OSAFO, S. ENNING \& H. ADU-DAPAAH \\ (K.O.A.: Council for Scientific and Industrial Research, Animal Research Institute, P. O. Box \\ AH 20, Achimota, Accra, Ghana; C.A. \& E.L.K.O.; Department of Animal Science, Kwame \\ Nkrumah University of Science and Technology-Kumasi, Ghana; S.E.\& H.A.D.: Council for \\ Scientific and Industrial Research - Crops Research Institute, Kumasi). \\ *Corresponding author's email: ojake6@yahoo.com
}

\begin{abstract}
A 90-day study on evaluating quantity and quality of manure from small ruminants in the Guinea Savannah agro-ecological zone of Ghana was conducted. 36 goats and 36 sheep were randomly allotted to three dietary treatments - Basal diets of maize stover, cassava and yam peels as Treatment one (T1), T1 supplemented with cowpea residues as Treatment two (T2) and T1 supplemented with groundnut residues as Treatment three (T3) in a randomized complete block design. Feed composition and intake and manure characteristics were assessed and data analyzed statistically using Generalized Linear Model procedures of SAS at 5\% significance level. The Chemical composition of feed resources ranged from 3.2-17.3\% crude protein, $82-97.2 \%$ organic matter and $2.8-18 \%$ ash. Total feed intake ranged from $519.55-659.72 \mathrm{~g} /$ day and $331.84-$ $420.17 \mathrm{~g} /$ day for sheep and goats respectively. Sheep manure weighed 319.17-423.33 g/day and contained $20.74-29.01 \%$ carbon, $1.87-2.32 \%$ nitrogen, $0.77-3.00$ potassium, $9.52-26.50 \%$ ash, $0.44-0.77 \mathrm{pH}$ and $\mathrm{C}: \mathrm{N}$ ratio of $10.98-15.53$. Goat manure weighed $178.67-216.17 \mathrm{~g} /$ day with $19.58-30.61 \%, 1.56-2.21 \%$ nitrogen, $0.82-2.33 \%$ potassium, $10.75-19.80 \%$ ash, $0.37-1.47 \mathrm{pH}$ and $\mathrm{C}: \mathrm{N}$ ratio of 9.49-19.92. Results indicated that manure from small ruminants could serve as alternative source of fertilizer in Ghana since its characteristics compare well with chemical fertilizers.
\end{abstract}

Keywords: sheep; goats; feed resources; manure; fertilizers

Short communication. Received 12 Nov 18; revised 20 Jun 19

\section{Introduction}

Smallholder farmers in potentially high agricultural areas often mine soil nutrients through crop extraction, weed removal, grazing livestock, cutting forage to feed livestock or selling fodder (Powell et al., 2004). After limited soil moisture, low soil fertility is the most important constraint limiting crop productivity in Sub-Saharan Africa (Gicheru, 2012; Fischer \& Qaim, 2012). In Ghana, for instance, almost all nutrient balances, that is, the difference between the quantities of plant nutrients applied and the quantities removed or lost, show a nutrient deficit (FAO, 2004) since

Ghana Jnl Agric. Sci. 54 (1), 67 - 76

GJAS is an Open Access Journal and distributed under the terms of the Creative Commons (CC) License [CC BY 4.0] 
nutrient depleting cultivation practices are still used extensively.

Nutrients from the soil support plants, and crop residues and forages fed to animals are recycled back to the cropland as manure (Bajracharya, 1999). Crop residues ("trash" or agricultural waste) are increasingly becoming a valuable feed resource for livestock (Hofstrand, 2009). About $25 \%$ of nitrogen (N) and phosphorus (P), $50 \%$ of sulphur (S), and $75 \%$ of potassium (K) uptake by cereal crops from the soil are retained in crop residues making them valuable nutrient sources (Dotaniya, 2013). A common practice of eliminating waste after crop harvest in many developing countries is to burn the crop residues left, leading to environmental pollution and loss of otherwise nutritious feed resource for livestock. If used strategically, a country like Ghana could save up to 186 million $\mathrm{kg}$ of livestock weight that is lost during the 120-day dry season from its 2.3 million tonnes of cereal crop residues produced (Amaning-Kwarteng, 1991).

Manure contains large amounts of organic matter, hence when used as a soil amendment, builds the soil and nourishes plants (Mitchell, 1992; Giyinyu et al., 2005). Application of organic amendments, like sheep and goat manure, increases soil organic matter, supply nutrients to crop, and stimulates the multiplication of organisms that are antagonistic to plant parasitic nematodes (Orisajo et al., 2007; Orisajo et al., 2008). Additional benefits of applying manure include increased soil cation Exchange Capacity (CEC), organic carbon and soil moisture content (Aggarwal et al., 1997; Kimani et al., 1999), which in turn enhances biological activity in the soil and ultimately, crop yield (Lekasi, 2001). Sheep and goat manure has been found to contain low C: $\mathrm{N}$ ratio below the critical level of 20 as reported by Saha et al., (2008) indicating their role in nitrogen mineralization and stabilizing farming systems.
Feeding sheep and goats with crop residues and other agro by-products are common practice amongst farmers in Ghana but evidence on the quantity and quality of manure produced from feeding these crop residues and by-products is scanty. The objective of this study was thus to evaluate the effects of feeding crop residues on the quantity and quality of manure generated by sheep and goats.

\section{Materials and Methods}

\section{Study area}

The study began in April 2014 at Atebubu and Amantin in the Atebubu-Amantin district of the Brong-Ahafo Region which falls in the Guinea Savannah agro-ecological zone of Ghana. Mean temperatures fluctuate between a minimum of $24^{\circ} \mathrm{C}$ and a maximum of $30^{\circ} \mathrm{C}$ (Ghana Statistical Service, 2013). The South-Southwest (SSW) wind blows with a speed of $6 \mathrm{kmh}^{-}$ ${ }^{1}$. The area receives bimodal rainfall distribution with a mean annual rainfall of 1400-1800 $\mathrm{mm}$ (Ghana Statistical Service, 2010). The major rainy season extends from May to August and the minor season lasts from September to November followed by the dry season from December to April.

\section{Selection of farmers and animals}

Purposive sampling was used in selecting sheep and goat farming project sites. Stratified sampling technique was employed to sample cereal and legume crop farmers, who also rear small ruminant (sheep and goats). 12 farmers comprising six farmers (three males and three females) from Atebubu and another six farmers (three males and three females) from Amantin were selected for the study. A total of 72 animals comprising 36 male West African Dwarf goats and 36 male West African Dwarf sheep aged 12-14 months were used in the 
study. Mean initial live-weights ranged from $14.85-15.17 \mathrm{~kg}$ and $10.00-10.30 \mathrm{~kg}$ for sheep and goats respectively. Feed, water and mineral salt lick (Sodium Chloride; Sodium content: $38.05 \%$ ) were offered ad libitum. Each farmer used six animals (three sheep and three goats) in the study.

\section{Experimental design and data analysis}

Animals were randomly allotted to three crop residue-based dietary treatments. Treatment one (T1) comprised a Basal diet of maize stover, cassava and yam peels; Treatment two (T2) being the supplementation of T1 with cowpea residues and Treatment three (T3) being supplementation of $\mathrm{T} 1$ with groundnut residues in a randomized complete block design. Each block (location - Atebubu and Amantin) had three dietary treatments and six replicates (animals) per treatment each for sheep and goats in each town. The animals were housed near the homes of each farmer. The animals were stall-fed ad-libitum with basal diets comprising mostly of cereal residues and kitchen waste comprising cassava and yam peels (about 5\% of the body weight of the animal with 3,1 and $1 \%$ maize stover, cassava peels and yam peels respectively). These basal feeds were supplemented with cowpea and groundnut residues at $300 \mathrm{~g} / \mathrm{animal} /$ day. Table 1 shows the percentage compositions of the experimental diets in both towns.

TABLE 1

Percentage (\%) nutrient composition (DM basis) of the experimental diets.

\begin{tabular}{|c|c|c|c|c|c|c|}
\hline \multirow[t]{3}{*}{ Composition } & \multicolumn{6}{|c|}{ Location } \\
\hline & \multicolumn{3}{|c|}{ Atebubu } & \multicolumn{3}{|c|}{ Amantin } \\
\hline & $T 1$ & $T 2$ & $T 3$ & $T 1$ & $T 2$ & $T 3$ \\
\hline Dry Matter & 84.2 & 88.04 & 84.5 & 83.6 & 89.4 & 88.8 \\
\hline Organic Matter & 89.4 & 91.2 & 91.1 & 89.0 & 85.6 & 88.5 \\
\hline Crude Protein & 6.41 & 11.5 & 11.6 & 5.32 & 10.2 & 10.3 \\
\hline Ash & 9.57 & 8.80 & 8.88 & 11.04 & 12.4 & 11.5 \\
\hline
\end{tabular}

Cited in Ansah et al (2014).

\# T1 = Basal diet of maize stover, cassava and yam peels; T2 = Treatment 2 (T1 supplemented with cowpea residues); T3 = Treatment 3 (T1 supplemented with groundnut residues). * All nutrient composition on DM Basis

The randomized complete block design (RCBD) was applied to the daily manure produced by sheep and goats in each town with the feed type being the treatments and the animals (sheep and goats) being the replicates. The feed was offered ad libitum twice daily (09:00 hours and 16:00 hours). The feed was weighed daily with a weighing scale before offering to the animals. Feed intake was measured and recorded daily as the difference between feed offered and feed refused.

All the data collected were statistically analysed using the Generalized Linear Model (GLM) procedures of SAS (SAS, 2006). All the statistical tests were done at a significance level of 5\%. The Waller K-ratio test was used to compare significant differences between the treatment means. 


\section{Parameters measured}

Two samples of each feed type per farmer were collected, pooled and taken to the Animal and Soil Science Laboratories of the Kwame Nkrumah University of Science and Technology (K.N.U.S.T.), Kumasi-Ghana for proximate analysis (Table 1) using procedures described by AOAC (2002). Manure sampling was done for 90 days after two weeks of adaptation to the feed. Daily manure produced by sheep and goats in each town were collected from pens every morning., Sample was then taken, pooled together, bagged and analysed for organic carbon, nitrogen, $\mathrm{pH}$, potassium and ash at the Crop and Soil Science Laboratories, K.N.U.S.T., Kumasi-Ghana.

\section{Results and Discussions}

Quality of sheep manure

The weight and quality of manure from sheep in the study areas are presented in Table 2 . Feed type affected the percent carbon $(p=0.0003)$, and nitrogen $(p=0.018)$, Carbon to Nitrogen $(\mathrm{C}: \mathrm{N})$ ratio $(p<0.0001)$, potassium $(p=0.005)$ and weight of manure produced by sheep $(p=0.0128)$. Feed type however did not affect $\mathrm{pH}(p=0.718)$ and Ash content of the manure produced by sheep $(p=0.2355)$. Nitrogen and potassium contents of sheep manure were higher $(p<0.05)$ in T2 and T3 than in $\mathrm{T} 1$. The high N contents of T2 and T3 could be attributed to the high crude protein contents in the supplements used in those treatments. Carbon contents and C: $\mathrm{N}$ ratio of sheep manure was higher for sheep on $\mathrm{T} 1$ than $\mathrm{T} 2$ and T3. The higher $\mathrm{C}: \mathrm{N}$ ratio of $\mathrm{T} 1$ could be attributed to the generally low crude protein contents of basal diets hence reduced nitrogen. The locational effect tended to approach significance for the weight of manure produced by sheep $(p=0.0636)$ but was different for percent carbon $(p=0.0288)$, carbon to nitrogen ratio $(p=0.0188), \mathrm{pH}(p=0.0009)$, potassium $(p<0.0001)$ and ash $(p=0.0135)$ content of manure produced by sheep.

The location however had no effect on the nitrogen content of sheep manure. An interaction existed between the feed and location for nitrogen $(p=0.0021)$, ash $(p=0.0009)$ and potassium content $(p=0.0106)$ as well as $\mathrm{pH}(p=0.0001)$ of manure produced by sheep. No location by feed interaction existed for weight $(p=0.0602)$, carbon $(p=0.1737)$ and $\mathrm{C}: \mathrm{N}(p=0.0630)$ of manure produced by sheep in the two locations. 
Manure characteristics of small animals...

TABLE 2

Quantity and chemical composition of Sheep manure in Atebubu and Amantin

\begin{tabular}{|c|c|c|c|c|c|c|c|c|c|c|c|}
\hline & \multicolumn{3}{|c|}{ ATEBUBU } & \multicolumn{3}{|c|}{ AMANTIN } & \multicolumn{2}{|l|}{$S E M$} & \multicolumn{2}{|c|}{$P$} & \multirow[b]{2}{*}{$\begin{array}{l}L O C^{*} \\
F E E D\end{array}$} \\
\hline & $T 1$ & $T 2$ & $T 3$ & $T 1$ & $T 2$ & $T 3$ & & $R E P$ & LOC & FEED & \\
\hline No. of Animals & 6 & 6 & 6 & 6 & 6 & 6 & & & & & \\
\hline $\begin{array}{l}\text { Mean live-weight } \\
\text { of sheep }(\mathrm{kg})\end{array}$ & 15.00 & 15.2 & 14.6 & 15.1 & 15.15 & 15.02 & & & & & \\
\hline Feed intake, g/day & $660^{\mathrm{a}}$ & $559^{\mathrm{b}}$ & $520^{c}$ & $677^{a}$ & $544^{\mathrm{bc}}$ & $554^{\mathrm{b}}$ & 13.1 & 0.200 & 0.267 & $<0.0001$ & 0.190 \\
\hline MWT, g & $378^{\mathrm{a}}$ & $391^{\text {ac }}$ & $423^{c}$ & $392^{\text {ac }}$ & $319^{b}$ & $399^{\text {ac }}$ & 17 & 0.220 & 0.0636 & 0.0128 & 0.0602 \\
\hline Carbon (g/kg DM) & $290.1^{\mathrm{a}}$ & $\begin{array}{l}254.0 \\
c\end{array}$ & 270.0 & $283.0^{\text {ad }}$ & $207.4^{\mathrm{b}}$ & $\begin{array}{l}259.0 \\
\text { c }\end{array}$ & 1.13 & 0.953 & 0.0288 & 0.0003 & 0.174 \\
\hline $\begin{array}{l}\text { Nitrogen }(\mathrm{g} / \mathrm{kg} \\
\mathrm{DM})\end{array}$ & $19.1^{\mathrm{a}}$ & $23.2^{\mathrm{b}}$ & $19.8^{\mathrm{a}}$ & $18.7^{\mathrm{a}}$ & $18.9^{\mathrm{a}}$ & $21.5^{\mathrm{b}}$ & 0.074 & 0.589 & 0.111 & 0.0180 & 0.0021 \\
\hline Carbon:Nitrogen & $15.5^{\mathrm{a}}$ & $11^{\mathrm{b}}$ & $13.6^{\mathrm{d}}$ & $15.1^{\mathrm{a}}$ & $11^{\mathrm{b}}$ & $12.1^{\mathrm{c}}$ & 0.317 & 0.0025 & 0.0188 & $<0.0001$ & 0.063 \\
\hline Acidity $(\mathrm{pH})$ & $0.68^{\mathrm{b}}$ & $0.77^{\mathrm{b}}$ & $0.51^{\mathrm{a}}$ & $0.45^{\mathrm{a}}$ & $0.44^{a}$ & $0.64^{\mathrm{b}}$ & 0.046 & 0.148 & 0.0009 & 0.718 & 0.0001 \\
\hline $\begin{array}{l}\text { Potassium }(\mathrm{g} / \mathrm{kg} \\
\mathrm{DM})\end{array}$ & $23.0^{\mathrm{b}}$ & $30.0^{\mathrm{d}}$ & $22.3^{\mathrm{b}}$ & $7.7^{\mathrm{a}}$ & $13.5^{\mathrm{c}}$ & $16.6^{\mathrm{c}}$ & 0.174 & 0.0202 & $<0.0001$ & 0.0050 & 0.0106 \\
\hline $\operatorname{Ash}(g / k g ~ D M)$ & $210.0^{\mathrm{b}}$ & $95.2^{\mathrm{d}}$ & 185.0 & $145.0^{\mathrm{a}}$ & $265.0^{\mathrm{c}}$ & $\begin{array}{l}253.0 \\
c\end{array}$ & 2.61 & 0.997 & 0.0135 & 0.236 & 0.0009 \\
\hline
\end{tabular}

"MWT=Manure weight, LOC=Location effect; FEED=Feed effect; LOC*FEED=Location by feed interaction. ${ }_{a, b, c}$ Means in a row with similar or no superscript are not different $(P>0.05)$.

The high $\mathrm{N}$ contents of $\mathrm{T} 2$ and $\mathrm{T} 3$ could be attributed to the higher crude protein contents in the feed supplements used in those treatments. Carbon contents and $\mathrm{C}: \mathrm{N}$ ratio of sheep manure was higher for sheep on T1 than T2 and T3 and could be attributed to the generally low crude protein contents of basal diet hence reduced nitrogen. The manure weights obtained in for sheep, was generally, similar to those (430-458 $\mathrm{g} /$ day) obtained by Irungu et al. (2005). Differences $(p<0.05)$ were observed in the percent carbon of sheep manure between T1, T2 and $\mathrm{T} 3$ in both towns. The differences in the carbon content of manure could be attributed to the nature of the feed, level of decomposition and losses as carbon dioxide $\left(\mathrm{CO}_{2}\right)$ (Larney et al., 2006). Differences $(p<0.05)$ were also observed in the total nitrogen content of sheep manure between T3 and the rest of the treatments in Amantin. Differences $(p<0.05)$ were also observed between all treatments for Total Nitrogen of manure in Atebubu.

Sheep on all treatments in both Atebubu and Amantin had a C: N ratio of 11-15.5 which was lower than the critical C: $\mathrm{N}$ ratio of 20 reported by Saha et al. (2008) below which net mineralization would readily occur when applied on soils.

Differences $(p<0.05)$ in the potassium and ash contents of sheep manure amongst all 
treatments in both towns could be attributed to the rate of leaching before collection and losses through urine (Kimani \& Lekasi, 2004).

Although there were differences $(p<0.05)$ in $\mathrm{pH}$ of sheep manure in Atebubu, it was observed that manure produced from all the farms were highly acidic which is in agreement with the assertion made by KATC (2004) that fresh manure is acidic. Differences $(p<0.05)$ were also observed in the Ash contents of manure produced by sheep in Atebubu which is an indication of a mixture with soil or varied inorganic component of the manure.

\section{Quality of goat manure}

The weight and quality of manure of goats in both towns (Table 3) indicate that feed type significantly affected the percent carbon $(p<0.0001)$, nitrogen $(p=0.0002), \mathrm{C}: \mathrm{N}$ ratio $(p<0.0001)$ and percent ash $(p=0.0167)$ contents of manure produced by goats. Feed type however did not significantly affect $\mathrm{pH}$ $(p=0.3562)$, percent potassium $(p=0.120)$ and weight $(p=520)$ of the manure produced by goats in the two locations.

Weight of goat manure was higher in $\mathrm{T} 1$ than T2 and T3. Nitrogen content of goat manure was higher in T2 and T3 than in T1. Manure from goats on $\mathrm{T} 1$ had a higher $(\mathrm{p}>0.05)$ carbon content and $\mathrm{C}$ : $\mathrm{N}$ ratio than for goats on $\mathrm{T} 2$ and T3. Ash, $\mathrm{K}$ and $\mathrm{pH}$ were all higher $(\mathrm{p}<0.05)$ in $\mathrm{T} 2$ than T1 and T3 in Atebubu (Table 3).

TABLE 3

Quantity and quality of Goat manure in Atebubu and Amantin

\begin{tabular}{|c|c|c|c|c|c|c|c|c|c|c|c|}
\hline & \multicolumn{3}{|c|}{ ATEBUBU } & \multicolumn{3}{|c|}{ AMANTIN } & \multirow[t]{2}{*}{$S E M$} & \multicolumn{4}{|l|}{$P$} \\
\hline & $T 1$ & $T 2$ & $T 3$ & $T 1$ & $T 2$ & $T 3$ & & $R E P$ & LOC & FEED & $\begin{array}{l}\text { LOC }{ }^{*} \\
\text { FEED }\end{array}$ \\
\hline \multicolumn{12}{|l|}{ Parameter } \\
\hline No. of Animals & 6 & 6 & 6 & 6 & 6 & 6 & & & & & \\
\hline $\begin{array}{l}\text { Mean live-weight } \\
\text { of goats }(\mathrm{Kg}) \text {, }\end{array}$ & 10 & 10 & 10.2 & 10.1 & 10.3 & 10.1 & & & & & \\
\hline $\begin{array}{l}\text { Feed intake }(\mathrm{g} / \\
\text { day), }\end{array}$ & 420 & 352 & 332 & 443 & 360 & 318 & 8.93 & 0.144 & 0.0355 & $<0.0001$ & 0.759 \\
\hline MWT (g), & $208^{a}$ & $218^{\mathrm{a}}$ & $180^{\mathrm{b}}$ & $210^{\mathrm{a}}$ & $179^{\mathrm{b}}$ & $216^{\mathrm{a}}$ & 10.2 & 0.432 & 0.958 & 0.520 & 0.0052 \\
\hline $\begin{array}{l}\text { Carbon }(\mathrm{g} / \mathrm{kg} \\
\mathrm{DM}),\end{array}$ & $306.0^{\mathrm{a}}$ & $258.0^{\mathrm{b}}$ & $196.0^{d}$ & $302.0^{\mathrm{a}}$ & $251.0^{\mathrm{b}}$ & $23^{\mathrm{c}}$ & 1.25 & 0.442 & 0.452 & $<0.0001$ & 0.202 \\
\hline $\begin{array}{l}\text { Nitrogen }(\mathrm{g} / \mathrm{kg} \\
\mathrm{DM}),\end{array}$ & $18.3^{\mathrm{b}}$ & $21.4^{\mathrm{cd}}$ & $20.7^{\mathrm{cd}}$ & $15.6^{\mathrm{a}}$ & $19.6^{\mathrm{bc}}$ & $22.1^{\mathrm{d}}$ & 0.091 & 0.999 & 0.183 & 0.0002 & 0.0826 \\
\hline Carbon: Nitrogen & $16.6^{\mathrm{b}}$ & $12.04^{\mathrm{c}}$ & $9.49^{d}$ & $19.9^{\mathrm{a}}$ & $12.9^{\mathrm{c}}$ & $10.4^{\mathrm{d}}$ & 0.924 & 0.435 & 0.036 & $<0.0001$ & 0.351 \\
\hline Acidity (pH) & $0.61^{\mathrm{a}}$ & $1.47^{\mathrm{b}}$ & $0.62^{\mathrm{a}}$ & $0.37^{\mathrm{a}}$ & $0.50^{\mathrm{a}}$ & $0.37^{\mathrm{a}}$ & 0.390 & 0.625 & 0.139 & 0.356 & 0.575 \\
\hline $\begin{array}{l}\text { Potassium(g/ } \\
\text { kgDM) }\end{array}$ & $22.9^{\mathrm{a}}$ & $23.3^{\mathrm{b}}$ & $22.3^{\mathrm{a}}$ & $8.2^{\mathrm{a}}$ & $14.7^{\mathrm{a}}$ & $15.2^{\mathrm{a}}$ & 1.700 & 0.528 & 0.0417 & 0.120 & 0.169 \\
\hline $\operatorname{Ash}(g / k g ~ D M)$, & $165.0^{\mathrm{b}}$ & $198.0^{\mathrm{b}}$ & $173.0^{\mathbf{b}}$ & $108.0^{\mathrm{a}}$ & $180.0^{\mathrm{b}}$ & $123.0^{\mathrm{a}}$ & 1.75 & 0.940 & 0.0082 & 0.0167 & 0.498 \\
\hline
\end{tabular}

${ }^{*}$ MWT=Manure weight, LOC=Location effect; FEED=Feed effect; LOC*FEED=Location by feed interaction. ${ }_{a, b, c}$ Means in a row with similar or no superscript are not significantly $(P>0.05)$ different. 
Location had an effect on the Carbon to Nitrogen ratio $(p=0.0188)$, Potassium $(p=0.0417)$ and ash $(p=0.0082)$ content of manure produced by goats but had little effect on percent Nitrogen $(p=0.183)$, Carbon $(p=0.452), \mathrm{pH}$ $(p=0.139)$ and weight $(p=0.958)$ of manure produced by goats. With the exception of the $\mathrm{C}$ : $\mathrm{N}$ ratio of goat manure, which was generally higher in Amantin, the weight as well as the Carbon, Nitrogen, K, Ash, C: N ratio and $\mathrm{pH}$ of manure produced by goat were generally higher in Atebubu than in Amantin. An interaction existed between the feed and location for weight $(p=0.0052)$ of manure produced by goats. No Location by feed interaction existed for Nitrogen $(p=0.0826)$, ash $(p=0.498)$, Carbon $(p=0.202)$ and Potassium content $(p=0.169)$ as well as of $\mathrm{pH}(p=0.575)$ and Carbon to Nitrogen ratio ( $p=0.351)$ of manure produced by goats in the two locations.

Weight of goat manure was higher in T1 than T2 and T3. Nitrogen content of goat manure was higher in $\mathrm{T} 2$ and $\mathrm{T} 3$ than in $\mathrm{T} 1$. The high N contents of T2 and T3 could be attributed to the high crude protein contents in the supplements used in those treatments. Carbon contents and $\mathrm{C}: \mathrm{N}$ ratio of goat manure was higher for $\mathrm{T} 1$ than $\mathrm{T} 2$ and $\mathrm{T} 3$. The higher $\mathrm{C}: \mathrm{N}$ ratio of $\mathrm{T} 1$ could be attributed to the generally low crude protein contents of basal diet hence reduced nitrogen content. Ash, $\mathrm{K}$ and $\mathrm{pH}$ were all higher in $\mathrm{T} 2$ than $\mathrm{T} 1$ and $\mathrm{T} 3$.

The range of values for Carbon (23$30.6 \%)$ and Total Nitrogen (1.56-2.21\%) were similar to the $26.4-38.1 \%$ organic Carbon and $1.4-2.3 \%$ Total Nitrogen reported by Moral et al. (2005) for goat manure. Also, a general assessment of the potassium values obtained in our study indicates that the values obtained for goats in Amantin are lower than the 2.4\% reported by Kausar (1983) for goat manures in the tropics. The range of values for $\mathrm{K}$ in Atebubu was however higher.

The C: $\mathrm{N}$ ratios for manures in both locations were lower than $20 \%$, which indicate potential or likely net Nitrogen mineralization if applied directly on soils. This is considered an important extra benefit of using manure as a soil amendment (Mando et al., 2005). The differences in $\mathrm{N}$ content of manure between treatments could be due to the differences in feed digestibility, the crude protein content of feed, nature of manure (amount of urine and feed refusals combined with faeces) and the level of volatilization of ammonia (lower in soils with low $\mathrm{pH}$ ).

High-quality manure has been defined as that with $\mathrm{N}$ content greater than $1.6 \%$ or $\mathrm{C}$ : $\mathrm{N}$ ratios less than 10 ; while low-quality manure has $\mathrm{N}$ content less than $0.6 \%$ and $\mathrm{C}$ : $\mathrm{N}$ ratio greater than 17 (Bationo et al., 2004). A general observation from the study was that although all the $\mathrm{C}$ : $\mathrm{N}$ ratio of sheep and goat manure in both communities were greater than 10 , their $\mathrm{N}$ contents were comparatively higher indicating the quality of manure produced.

It was also observed that manure produced from all the animals were highly acidic which was in agreement with the assertion made by KATC (2004) that fresh manure is acidic. This manure when applied on the soil would make it acidic hence amendments aimed at neutralizing acid content is needed when applying fresh manure from sheep and goats fed crop residue-based diets on soils.

From the results obtained, it is estimated that a WAD sheep of an average weight of $15.0 \mathrm{~kg}$ is capable of producing as much as $138 \mathrm{~kg}$ of manure on DM basis per year, supplying $2.63 \mathrm{~kg} \mathrm{~N}$ and $3.17 \mathrm{~kg} \mathrm{~K}$ per annum. Similarly, a WAD goat with an average weight of $10.0 \mathrm{~kg}$ is capable of producing $79.7 \mathrm{~kg}$ of 
manure on DM basis per year, supplying 1.71 $\mathrm{kg} \mathrm{N}$ and $1.86 \mathrm{~kg} \mathrm{~K}$ per annum. Osuhor et al. (1998) reported similar values $(3.00 \mathrm{~kg} \mathrm{~N}$ and $1.2 \mathrm{~kg} \mathrm{~K}$ ) for Red Sokoto goats. This indicates that the fertilizer value of sheep and goat manure is comparable to Nitrogen and Potassium values in inorganic fertilizers and with the reported 10.3 million small ruminant population in Ghana (SRID, 2014), the tonnes of manure they are capable of producing on DM basis can significantly reduce or replace the quantity of the inorganic fertilizers used by the farmers. The general recommended $\mathrm{N}$ and $\mathrm{K}$ rate for a crop like maize in Ghana is $90 \mathrm{~kg} \mathrm{~N}$ and $60 \mathrm{~kg}$ $\mathrm{K}_{2} \mathrm{O}$ per hectare (Adu et al., 2014). From the study, a total of 30-50 goats and 20-35 sheep fed crop residue-based diets can achieve this $\mathrm{N}$ and $\mathrm{K}$ rates required for optimum growth and increased productivity of maize. This not only makes beneficial use of crop residues but also help meet the fertilizer needs of crops and crop farmers alike. Since these manures are much cheaper and could even be obtained free of charge, crop farmers need to be encouraged to consider using them to fertilize their crop fields.

\section{Conclusion}

Supplementing small ruminant feed with leguminous residues resulted in manure with relatively higher Nitrogen contents than those without such supplements. Such manures have great potential as a substitute or alternative for relatively expensive inorganic fertilizers for amending low fertile soils in rural towns. The fertilizer value of sheep and goat manure is comparable to nitrogen, potassium and carbon values in inorganic fertilizers commonly used in Ghana indicating their potential role in amending soils of declining fertility. As campaigns for organic food productions is on the rise, crop farmers can take advantage of using sheep and goat manure to fertilize their farms.

\section{Acknowledgement}

Our sincere gratitude goes to AUSAID and CORAFSIR-CRI for their support. To all the participating farmers, Agricultural Extension staff, Researchers and Scientists in the CORAF-AusTrade crop-livestock integration project in the Atebubu-Amantin District.

\section{REFERENCES}

Adu, G. B., Abdulai, M. S., Alidu, H., Nustugah, S. K., Buah, S. S., Kombiok, J. M., Obeng-Antwi, K., Abudulai, M. \& Etwire, P.M. (2014) Recommended Production Practices for Maize in Ghana. Savanna Agricultural Research Institute/ Alliance for Green Revolution in Africa publication. https://www.researchgate.net/ publication/270511013 Recommended Production Practices for Maize in Ghana. DOI: 10.13140/2.1.4376.3527. Accessed 21 September 2018 .

Aggarwal, R. K., Praveen, K. \& Power, J. F. (1997) Use of crop residue and manure to conserve water and enhance nutrient availability and pearl millet yield in an arid tropical region. Soil and Tillage 4, 43 - 51.

Amaning-Kwarteng, K. (1991) Sustainable dry season feeding of ruminants in Ghana. The use of crop residues and leguminous shrubs as feedstuffs. In: The complementarity of feed resources for animal production in Africa. Proceedings of the Joint Feed Resources Networks workshop held in Gaborone, Botswana, $4-8$.

Ansah, K. O., Antwi,C., Ennin, S., Amoah, S., Osei-Adu. J., Osafo, E.L. K. \& Adu-Dapaah, H. (2014) Monitoring the feed intake and growth performance of Small Ruminants in the Atebubu-Amantin District. Ghanaian Journal of Animal Science, 8 (1), 87 - 93. 
AOAC (Association of Official Analytical Chemists) (2002) Official Methods of Analysis, 17th Edition. AOAC: Washington, D.C.

Bajracharya, B. (1999) Sustainable Soil Management with Reference to Livestock Production Systems'.Paper presented at the joint International Centre for Integrated Mountain Development-Food and Agricultural Organization (ICIMOD-FAO) workshop on Mixed Crop-Livestock Farming System in High-Pressure Areas of the Himalayan Region, ICIMOD, Kathmandu.

\section{Bationo, A., Nandwa, S. M., Kimetu, J. M., Kinyan-} gi, J. M., Bado, B. V., Lompo, F., Kimani, S., Kihanda, F. \& Koala, S. (2004) Sustainable intensification of crop-livestock systems through manure management in eastern and western Africa: lessons learned and emerging research opportunities. In: Williams, T.O., Tarawali, S., Hiernaux, P., Fernandez- Rivera, S. (Eds.), Proceedings of the International Conference on Sustainable Crop-livestock Production for Improved Livelihoods and Natural Resource Management in West Africa. International Livestock Research Institute, Addis Ababa, Ethiopia, 173 - 198.

Dotaniya, M. L. (2013) Impact of various crop residue management practices on nutrient uptake by rice-wheat cropping system. Current Advances in Agricultural Sciences 5, 269 - 271.

FAO (Food and Agriculture Organization) (2004) Scaling soil nutrient balances. FAO Fertilizer and Plant Nutrition Bulletin No. 15. Rome.

Fischer, E. \& Qaim, M. (2012) Linking smallholders to markets: determinants and impacts of farmer collective action in Kenya, World Development 40, $1255-1268$.

Gicheru, P. (2012) An overview of soil fertility management, maintenance and productivity in Kenya, Archives of Agronomy and Soil Science 58(1), $22-32$.
Giyinyu, B. M., Ahonsi, S. O. \& Barau, M. (2005) Effects of different types of organic manure on growth and yield of tomato var. VFN. Proceeding of the 1st National Conference on Organic Agriculture in Nigeria held. University of Agriculture. Abeokuta. Nigeria. 25th to 28th October, 2005. pp. 28.

GSS (Ghana Statistical Service) (2010) 2010 National Analytical Report. GSS Accra, Ghana.

GSS (Ghana Statistical Service) (2013) Regional Analytical Report, Brong Ahafo Region. GSS, Accra, Ghana.

Hofstrand, D. (2009) Crop residue - a valuable resource. Agricultural marketing resource center. Renewable Energy Newsletter. 1 - 5.

Irungu, K. R. G., Ashiono, G. B., Ondabu, N. and Indetie, D. (2005) Manure output and its nutrient composition when sheep were fed on three cultivars of sweet potato vines. Conference Proceedings of African Crop Science 7, $551-554$.

KATC (Kasisi Agricultural Training Centre) (2004) Manure handling and storage. Study Circle manual, KATC, Lusaka, Zambia. In assoc. Swedish Cooperative Centre.Kausar, R. (1983) Review on recycling of animal wastes as a source of nutrients for freshwater fish culture within an integrated livestock system. Pakistan Agricultural Research Council, Islamabad, Pakistan. pp. 49.

Kimani, S. K. \& Lekasi, J. K. (2004) Managing manures throughout their production cycle enhances their usefulness as fertilisers: A review. In: Bationo A. (Ed.) Managing Nutrient Cycles to Sustain Soil Fertility in Sub-Saharan Africa. Tropical Soil Biology and Fertility Institute of the International Center for Tropical Agriculture (CIAT-TSBF), Nairobi, Kenya.

Kimani, S. K., Mangele. N., Gathua, K. W., Delve, R. \& Cadish, G. (1999) Effect of bean-maize intercropping, phosphorus and manure ad- 
dition on nitrogen fixation and grain yield of Phaseulus Vulgaris in Central Kenya. Proceedings of the 6th Kenya Agricultural Research Institue (KARI) Scientific Conference, Nairobi, Kenya, 205 - 211.

Larney, F.J., Buckley, K.E., Hao, X. \& McCaughey, W.P. (2006) Fresh, Stockpiled, and Composted Beef Cattle Feedlot Manure: Nutrient Levels and Mass Balance Estimates in Alberta and Manitoba. Technical Reports: Waste Management. Journal of Environmental Quality 35, $1844-1854$.

Mando, A., Ouattara, B., Somado, A. E., Wopereis, M. C. S., Stroosnijder, L. \& Breman, H. (2005) Long-term effects of fallow, tillage and manure application on soil organic matter and nitrogen fractions and on sorghum yield under Sudano-Sahelian conditions. Soil Use and Management 21, 25 - 31. DOI:doi. org/10.1079/SUM2005287. Accessed 18 October 2018

Mitchell, C. (1992) Using livestock manure as fertilizer. Extension Agronomist, Agronomy. Auburn University.

Moral, R., Moreno-Caselles, J., Perez-Murcia, M D, Perez-Espinosa A, Rufete, B. \& Paredes C (2005) Characterisation of the OM pool in manures. Bioresource Technology, 96(2).
Orisajo, S. B., Okeniyi, M. O., Fademi, O. A. \& Dongo, L. N. (2007) Nematicidal effects of waterleaf extracts of Acalypha ciliata, Jatropha gossypifolia, Azadirachta indica and Allium ascalonicum on Meloidogyne incognita infection on cacao seedlings. Journal of Research in Biosciences 3(3), 49 - 53.

Orisajo, S. B., Afolami, S. O., Fademi, O. \& Atungwu, J. J. (2008) Effects of poultry litter and carbofuran soil amendments on Meloidogyne incognita attacks on cacao. Journal of Applied Biosciences 7, $214-221$.

Osuhor, C. U., Alawa, J. P. \& Lufadeju, E. A. (1998) Overnight manure production from red Sokoto goats in Zaria, Nigeria. Proceedings of the Silver Anniversary of the Conference of the Nigeria Society of Animal Production. Gateway Hotel. Abeokuta. Nigeria. 21-26 March, 1998. $51-52$.

Powell, J. M., Pearson, R. A. \& Hiernaux, P. (2004) Crop-Livestock Interactions in the West African Drylands. Agronomy Journal 96, 469 483.

SAS. (2006) SAS user's guide: Statistics. 8th ed. SAS Institute, Inc., Cary, NC.

Saha, H. M., Kahindi, R. K. \& Muinga, R. W. (2008) Evaluation of manure from goats fed panicum basal diet and supplemented with madras thorn, leucaena or gliricidia. Tropical and Subtropical Agroecosystems 8 (2008), 251 - 257. 